\title{
Debate
}

\section{History, geography and world-systems theory}

\section{Gerry Kearns}

Peter Taylor's Political geography: world-economy, nation-state and locality presents the work of Immanuel Wallerstein to geographers in a clear and accurate fashion. ${ }^{[1]}$ It reconnects political geography and political science, mapping Mackinder onto Spykman and Whittlesey onto Deutsch. It urges that human geography be a historical social science. Elsewhere, Taylor has teasingly averred "that all geography is historical geography", and has argued that the world-systems project speaks to the best of "traditional (that is pre-socialscience) geography" which "left a holistic legacy to geography that was at variance with the growing specialisation in the natural and social sciences". ${ }^{[2]} \mathrm{He}$ claims that in its preoccupation with the state "much of modern geography ha[s] in fact abandoned its global heritage" and that he has, therefore, turned from Marxist geography "to embrace an equally rich but alternative geography to be found in Wallerstein's Historical capitalism. The most fruitful geographical analyses have never been the prerogative of geographers, sensu strictu" ${ }^{[3]}$ In complementary fashion, Wallerstein's scheme "locates geography at centrestage instead of being a spatial appendix to social science". ${ }^{[4]}$ In this essay I want to look at two of the ways in which we might be persuaded to adopt the worldsystems project: methodological and historical argument. Taylor is faithful to the intentions of Wallerstein's work and I shall claim that there are problems with the project which are central to Wallerstein's major historical studies. The essay concludes with a sketch of the problematic relations between theory and practice in the project. The essay has little to offer on the philosophy of science and modern political studies of Wallerstein or Taylor. I also say nothing about Wallerstein's co-workers or about the many other big-picture histories from outside the Wallerstein camp. This is not because I do not recognise these issues as important. On the philosophical questions there already exist two interesting papers. ${ }^{[5]}$ The other ignored issues would require extended treatment in their own right. Here I shall argue that the methodological principles Taylor takes from Wallerstein are far from being unique to the world-systems project and that, indeed, they are followed only fitfully by Wallerstein himself. On historical grounds, I have reservations about the way Wallerstein treats those mechanisms which he claims are constitutive of a modern world-system. Throughout I shall try to pay close attention to the purpose of Wallerstein's work, a historically and theoretically informed approach to the advance of socialist politics. 


\section{Wallerstein's methodology and the modern world-system as an entity}

From Wallerstein, Taylor takes three methodological principles, a commitment to the modern world-system as an object of study and a threefold characterisation of that entity. In this section I consider the approach to and definition of the modern world-system. In the next, I take up the historical arguments.

Wallerstein's methodological claims are as follows, Firstly, taking up the substantivist critique of economic theory, Wallerstein follows Polanyi in attacking the "myth of universal laws". Market rationality, far from being a basic human attribute, flourishes under a quite specific set of institutional arrangements. Secondly, from Braudel, Wallerstein absorbs an interdisciplinary rhetoric castigating the "poverty of disciplines". Thirdly, from Frank, comes an abhorrence of the "error of developmentalism". The separate nation-states of the world-economy are not autonomous entities passing through a sequence of stages which together constitute a development process, fundamentally the same from place to place, like the symptoms of a progressive or debilitating illness.

The first point I want to make about these three methodological principles - the myth of universal laws, the poverty of disciplines and the error of developmentalism - is that geographers will find them in many other places than in Wallerstein and sometimes more forcefully and elaborately argued. The historical relativity of market rationality is comprehensively treated from a political and cultural point of view in the work of Max Weber and in an empirical manner in the work of many early-twentieth century economic-historical sociologists: Unwin, Sombart, Gras for example. The social history of markets is interestingly treated by the property-rights theorists and the new institutional economics. I do not share the optimism of Coase, Posner or North that institutions are optimally selected by market forces but I would agree that they are subject to economic pressures making the interplay of behaviour and context more complex than allowed for by either universal laws or substantivist anthropology. The argument for an interdisciplinary approach is advanced in almost every discipline and histoire totale is not obviously more attractive than cultural ecology, pragmatic literary criticism or historical materialism. Indeed a more adequate approach would surely reconsider the institutional basis of disciplines and review the intellectual dynamics of this poverty of disciplines. In a work of similar scope but different focus, Eric Wolf does just this and Europe and the people without history makes a case for a Polanyi-type of Marxism out of the varieties of social responsibility which disciplinary fragmentation was implicitly evolved to deny. ${ }^{[6]}$ If identifying the error of developmentalism is primarily a plea for a more contextual approach, then it has long been the very stuff of historians' and geographers' quibbles with economists and sociologists. Of course these debates, in the simplistic form of idiographic versus nomothetic approaches, have also run through as well as from history and geography. If we shift the basis of the critique of developmentalism a little, to cover essentialist models of the economy, then geographers have the very fruitful Hindess and Hirst tradition to draw on.

The second point I want to make about these principles is that Wallerstein does not actually stick to them. He does not pay much attention to the history of market institutions, to the evolution of rationality or, despite commenting on the immorality of profit-seeking in medieval Europe, to the psychosocial dynamics of the work ethic, which he refers to as "the incorporation within our 
very superegos of the compulsion to work" ${ }^{[7]}$ As for the poverty of disciplines, Wallerstein is forced, like all scholars, to betray his universalist rhetoric, ignore many sides of histoire totale ("the impossible dream") and write, particularly in Modern world-system II, basically a diplomatic history with a certain measure of background economic information. ${ }^{[8]}$ Yet it is his developmentalism which is perhaps most shocking. This certainly carries most polemical weight in his writings. Some of this may be just shorthand for empirically-based generalisations as when he speaks of world wars restructuring the world-economy in the early-seventeenth, turn-of-the-nineteenth and mid-twentieth centuries: "It is to be noted", writes Wallerstein, "in each case, the victor had been primarily a maritime power prior to 'world war', but had transformed itself into a land power in order to win this war against a historically strong land power which seemed to be trying to transform the world-economy into a world-empire."[9] However, more serious still is Wallerstein's developmental sequence for the "core-state-cycle", as we might call it. The rise and fall of states, argues Wallerstein, is powered by their productivity which is a function of technology and wages. A low-wage state with weak labour introduces a technology improving its productivity. It rises to productive hegemony among core states, in its train this brings commercial hegemony as the state comes to dominate trade, on the back of its exports, leading to financial hegemony as its leadership secures it sound-money status and its growth makes it a safe place for credit. All the time, its prosperity makes the bourgeoisie tempted to buy off working-class pressure with higher wages funded out of exports and thus essentially out of unequal exchange with the rest of the world. Social imperialism fuels inflation at the very time that other countries, now with relatively low wages, copy the new technologies, and thus productive hegemony is surrendered. For a while the specialist skills of merchants maintain trade hegemony before even that goes and the financial hegemony lingers on as the country serves as an efficient clearing house passing domestic and foreign investments to the new productive leader in the core. In turn this new leader attracts to itself trading and financial functions and in decline the old leader reverts to low wage status awaiting any new developments. Wallerstein concludes: "These superiorities are successive, but they overlap in time. Similarly, the loss of advantage seems to be in the same order (from productive to commercial to financial), and also largely successive" ${ }^{[10]}$ and he sets the model out explicitly for seventeenth-century Dutch hegemony. ${ }^{[1]}$ Inflation and war go hand in hand as the economic and political dimensions of the geographical restructuring of the world economy during periods of stagnation, although the two dimensions may have different chronologies. ${ }^{[12]}$ Not only is Wallerstein keen to embrace a cyclic, although not linear, developmentalism which applies to states, not systems or entities, he is also keen to give his whole history the most explicit teleological basis. The intention of the system was to polarise benefits spatially.in a way which belies the progressive balance sheet which could be drawn up for the current leaders of the core. In an astonishing passage he writes "If this is so, why did such a system arise? Perhaps, precisely to achieve this end. What could be more plausible than a line of reasoning which argues that the explanation of the origin of a system was to achieve an end that has in fact been achieved? I know that modern science has turned us from the search for final causes and from all considerations of intentionality (especially since they are so inherently difficult to demonstrate empirically). But modern science and historical capitalism have been in close 
alliance as we know; thus, we must suspect the authority of science on precisely this question: the modality of knowing the origins of modern capitalism." $[13]$

Out of these methodological principles, and from an observation of the constraints on autonomous political and economic development in contemporary African states, Wallerstein fashions his commitment to the study of the modern world-system as the appropriate object of study, a self-sufficient entity, unlike states, and a historical, multi-state totality.

It would be intriguing to draw out Wallerstein's epistemological commitments, they include rational a priori knowledge (his reasoning from the mystical value of the number three) and a form of categorical essentialism akin to the reification of system in general systems theory; perhaps he has not moved far enough from American political science. But epistemology is a virus, and Peter Taylor has caught it badly with his political economy of scale. If we need an epistemology at all it would presumably connect the following: real events, a method of studying them and a set of concepts which describes them. Taylor, following Wallerstein, conflates all three. Speaking of the mere possibility of writing local studies he warns that "Since the world-economy is a holistic concept, however, it follows that one scale of analysis cannot be hived off and studied separately any more than economic or political processes can be treated in isolation." "[14] This might be viewed as merely an extravagant plea for context but, no, we are told that only the world-system/world-scale is real because it is the whole: "By 'reality' we are referring to the holistic reality that is the concrete world-economy which incorporates the other scales. It is in this sense the totality of the system. Hence ultimate explanations within the system must be referred back to this 'whole'. It is the scale that 'really matters'." ${ }^{[15]}$ Holistic relates to concepts, scale relates to measurement or method and whole relates to reality yet here these distinctions are completely collapsed. Out of this mishmash, relations and identities defined at one level are asserted at another. And this is precisely what Wallerstein does too. The polemical force of insisting on writing about historical capitalism derives from equating historical with actual or real as opposed either to the logico-deductive (purely conceptual) model of Capital volume one or the anachronistic "mythologised foil""[16] used in, perhaps, Mandel to point up the specifics of actual, modern, late capitalism. No, says Wallerstein, capitalism as actuality is historical, is a system, a world-economy fundamentally unchanging since its establishment as such, in the sixteenth century, a watershed he compares to the invention of agriculture during the Neolithic ${ }^{[17]}$ The whole defines the parts, ${ }^{[18]}$ so that, for example, Wallerstein asks "Is it conceptually useful to apply the label 'proletarian' to an individual? I doubt it." ${ }^{[19]}$ Because individuals are parts of households where much of the labour that is allocated, demeaningly termed "domestic", is not done in return for wages. These distinctions are maintained at the level of the "legal and para-legal apparatus of gender distinction and discrimination". ${ }^{[20]}$ One might have expected some sort of heuristic defence of the political economy of scale, some demonstration of its conceptual value in theorising certain sets of social relations. But, no, what we actually get from Taylor is a sort of epistemological fiat. The global just is real. Suggesting that the world-scale alone is real, that the local-scale is merely experience he sees the state separating local political experience from global economic reality. Hence we get what Taylor terms his "political economy of scale". The economic reality is a zero-sum game but the state ideologically presents it as a choice and in another classic conflation of category and reality he writes "The role of all three-tier structures is the 
promotion of a middle category to separate conflicting interests. In our model, therefore, the national stage becomes the mediator between global and local scales." "21] This addition of a mystical belief in the properties of the number "three' also receives its imprimatur from Wallerstein. ${ }^{[22]}$ At the close of the first volume, Wallerstein reminds us that the whole defines its parts so that "the emergence, consolidation, and political roles of classes and status groups must be appreciated as elements of this world-system". And then he goes on to set out the following staggering description of class struggle: "since in conflict situations, multiple fractions tend to reduce to two by virtue of the forging of alliances [note that he assumes they are stable], it is by definition [again collapsing category and reality] not possible to have three or more (conscious) classes". ${ }^{[2]}$ The class consciousness of the ruling class, though, will sharpen that of the oppressed. Spatially, the same is true and to counter the polarisation of core and periphery the semi-periphery makes exploitation less direct and the perception of fundamental relations less likely, an alliance of core and semi-periphery or of semi-periphery and periphery is ruled out by the contradictory pulls on the semi-periphery: a mystifying trinity.

\section{The modern world-system as a reality}

Does it all matter? Moving from methodology to history, how adequate are the empirical studies? Let us examine the structure of Wallerstein's world-systems model in terms of the three criteria he himself defines it by. These three criteria are: a single world market, a multiple states system and a three-tier economic geography. This gives us the modern world-system which since the sixteenth century in essence "had not changed at all (such that we could denote the entire reality under one name)". ${ }^{[24]}$ A short-hand summary of my remarks on these three features might be: no win, no change, no evidence.

Under a single world market, the economic autonomy of each part of the system is destroyed, decisions about the allocation of resources take place in a framework where the fundamental signals derive from the situation of the place within the chains of commodity production, distribution and exchange which make up the world-economy. ${ }^{[25]}$ This is an important claim because it underwrites Wallerstein's politics of despair, his zero-sum interpretation of national politics. This has been the situation, Wallerstein insists, since the sixteenth century. Yet Wallerstein, in common with most economic historians, has great difficulty documenting the behavioural context of economic decision-making in the past. Rather, he confines himself to inferring the economic context of national political decisions. He claims, again and again, to uncover the economic group interests behind international diplomacy and, just as frequently, locates those economic group interests in the group/state's world-economy situation. However, this assumes that most production is market oriented, that most markets are integrated into national and international trading systems, that these markets reflect costs of production at different locations, that the markets balance and that inefficiency is an unacceptable and impossibly high price to pay for autarky. Wallerstein may bring space back into social science but he certainly does not carry any brief for distance. Yet to speak of market integration in sixteenth-century Europe is to fly in the face of overwhelming evidence that most producers were food producers, that the bulk of production was consumed on the farm and only a residual surplus was marketed and that the cost of inland transport was so high that the 
possibility of much food entering international markets was slight. Even in terms of national markets, inter-regional specialisation was only deepening over the seventeenth century and England is considered advanced in eliminating a largely self-sufficient peasantry by the sixteenth century. With this proviso Dodgshon is willing to accept Wallerstein's analysis from the nineteenth century, implicitly consigning both published volumes to marginalia and, no doubt, eagerly awaiting the next. ${ }^{[26]}$ Distance to market means that prices reflect more than just costs of production. Yet doubts about Wallerstein's explanation of economic change and political context are increased by the fact that he nowhere pursues the question of how important international trade was to domestic production. This is not an easy topic but I am persuaded by O'Brien and others that Britain's rise to productive hegemony in the eighteenth century did not involve either a large proportion of British raw material needs being met by imports or that a large volume of its production featured as exports. ${ }^{[27]}$ Unequal exchange makes this evaluation difficult and providing a model of a shadow economy with domestic lumber or cotton harvested at English rural wage-rates or with reduced demand is almost impossible. Nevertheless, in sheer volume terms, the isolation of much production from international markets means that the multiplier effects of international trade would have to be outstanding for this to explain Britain's prosperity. Rather than a world system it is the local and intense exploitation of Ireland which stands most chance of supporting Wallerstein's model. Finally, what exactly does the single world market balance? Unequal exchange means it balances both force and productivity; as well as transport costs of course. This multiple determinacy means that arguing cause and effect is difficult. Certainly the competitive advantage of low defence spending to Japan and Germany is clear since 1945, whereas the brutality of the USA in keeping the markets of poor countries open to unequal exchange has been spectacular. Always assuming markets do balance, and there are three reasons why they don't. Firstly, exchanges do not reflect scarcity as much as the unequal distribution of desparation to exchange. Secondly, exchanges are not simultaneous although the velocity of circulation has been increasing (with bi-annual fairs for many commodities in much of sixteenth-century Europe, what must it have been like then?). Thirdly, there is no regulatory body which can bring deficits and surpluses together faced with the intransigence of powerful economies. Only where there is only one strong economy is the world economy stable in the face of this blatant exploitation. Taken together, these observations on a single world market highlight Wallerstein's unbounded faith in the efficiency and pervasiveness of international markets. Against this I would argue that the way national economies are put together directly affects productivity, this is not a zero-sum game. The distribution of benefits and resources in society directly feeds through to productivity. Wallerstein is too pessimistic and the management of national economies does matter, as Therborn has shown for unemployment in Europe. ${ }^{[28]}$

Turning to the multiple states system, we find Wallerstein's faith in the efficiency of markets supported by a disturbing faith in the prescience of the bourgeoisie. Were the multiple states system to be replaced by a single world empire the political control of markets would mean that what Dodgshon terms less well-adapted zones of unused freedom ${ }^{[29]}$ would be filled up with complete adaptation to prevailing patterns of production. Wallerstein writes that "The states developed and were shaped as integral parts of an interstate system, which was a set of rules within which the state had to operate and a set of 
legitimisations without which states could not survive. From the point of view of the state-machineries of any given state, the interstate system represented constraints on its will." "[30] Military elites often try to establish world empires and Wallerstein concludes that "If such thrusts never succeeded in historical capitalism, it was because the structural base of the economic system and the clearly-perceived interests of the major accumulators of capital were fundamentally opposed to a transformation of the world-economy into a world-empire." ${ }^{[31]}$ How the collective committee of national bourgeoisies articulate this perceived interest we are not told. This functionalism also relates to the formation of the bourgeoise: through states in the core and nations in the periphery. In the core there "was a reasonably high level of continuity between the families that had been high strata in 1450 and those that were high strata in 1650. Furthermore, if one substituted 1900 for 1650 , one would find that most of the comparisons with 1450 still hold true". ${ }^{[32]}$ Between 1450 and 1650 the tendency towards egalitarian small peasant systems of production was halted by the bourgeoisie fighting within itself to direct the state in restructuring the economy; liberty and democracy were ideological weapons in "intra-bourgois struggles". ${ }^{[3]}$ State formation represents the transformation of a landed aristocracy into a national bourgeoisie: "historical capitalism was brought into existence by a landed aristocracy which transformed itself into a bourgeoisie because the old system was disintegrating". ${ }^{[3]}$ The transition to capitalism, therefore, did not involve a bourgeois revolution: "If there was no bourgeois revolution, does that mean there has been or will be no proletarian revolution? Not at all, logically or empirically. But it does mean we have to approach the subject of transitions differently." ${ }^{[35]}$ Wallerstein sees the ruling class families of 1900 evaporating but they might yet pull the iron from the fire by making society egalitarian and their hegemony more stable. Yet the real challenge comes from anti-systemic forces in the semi-periphery. Here states are created as cultural entities, the political expression of ethnic communities. The nationalistic bourgeoisie in such countries are co-opted cadres leading their cheap labour into an unequal world market but one which promises them as leaders the consolation of rationalism and the chimerical promise of the American dream. The important thing, though, is that the ideology of decolonisation, nationalism and socialism are all part of the evolution of historical capitalism, the latest veneer on the search of core capital for peripheral cheap labour. The communist countries, we are told, are functional for capitalist accumulation in precisely this way. For Wallerstein, the no-win situation imposed by efficient markets is reinforced by the no-change scenario spelled out by an all-seeing, all-adjusting world bourgeoisie.

Of course, what all of this denies is qualitative changes in the relations of production and the centrality of the class struggle to which the bourgeoisie must respond. Instead, access to resources is determined by prices not power and the strength of the bourgeoisie is indicated by economic productivity rather than working class pressure. Out of all this, Brenner convicts Wallerstein of retreating from Marx to Smith. ${ }^{[36]}$ But Wallerstein might claim to have an answer. Remember, his world system has three regions: core, semi-periphery and periphery and these contain differing mixtures of two sets of processes: exploiting and exploited, high wage and low wage, high technology and low technology. These higher wages reflect bourgeois concessions to working-class pressure, are funded out of exploitation of the periphery and express themselves as a relaxation of the intensity of exploitation of labour, an increase in the extent 
to which the costs of the reproduction of labour power are passed outside the home, and a recognition that labour in the core is generally high status. It is in this sense that labour in the core is considered scarce and jobs are highly capitalised. This is a tendency towards proletarianisation for free labour. The share-cropping and slavery labour systems of semi-periphery and periphery respectively in sixteenth-century agriculture reflect weaker proletarianisation and successively higher degrees of labour coercion. ${ }^{[37]}$ Thus European expansion overseas was primarily a search for a cheaper and "more tractable labour force". ${ }^{[38]}$ Yet Wallerstein wants it both ways because there were also settler colonies to which labour was sent. Underemployed at home, they did not generate sufficient demand for manufactured goods; fully employed abroad they could generate the demand against which colonial staples might exchange, thereby reducing the export of bullion from Britain. However, underemployment at home in the seventeenth century when the major concern of England and France was to find employment for their workers does not square well with labour scarcity arguments and high wages. Much of the cheap coerced labour of the periphery before the nineteenth century was not employed producing the goods which were already being made in the core with extensive labour. It was a switch to new lines of production (such as silver mining, sugar production) or an expansion in the sheer volume of production (as in lumber or corn) rather than a shift within an existing product mix between high- and low-cost labour inputs. Despite the obvious attraction of not doing so, Wallerstein refuses to recognise a continuum in the degree of coercion of the labour force from core to periphery. Although he tries to set out a qualitative difference between wage labour, share-cropping and slavery it would appear that these precise forms are contingent and largely confined to the period of agrarian world capitalism. ${ }^{[39]}$ While industrial labour can be coercive it takes rather different forms. Thus the position of the semi-periphery is defined as intermediary in commodity chains, exploiting the periphery and being exploited by the core. Yet Wallerstein must concede that this is a matter of degree and to understand why the separate existence of a semi-periphery is so important to him we need to look at the role he expects it to perform: "these middle areas ... partially deflect the political pressures which groups primarily located in peripheral areas might otherwise direct against core states and the groups which operate within and through their state machineries". ${ }^{[40]}$ In addition to this political functionality, the contrasting systems of labour help the differentiation of separate lines of production or links in the commodity chain, "each mode of labour control is best suited for particular types of production" and without three separate zones "it would not have been possible to assure the kind of flow of the surplus which enabled the capitalist system to come into existence". ${ }^{[41]}$ In the two volumes of empirical history Wallerstein has given us there is little of any substance to support these claims. The periphery of the world economy in the eighteenth century was being directly coerced by the core and it was the British in India and in the Caribbean rather than, say, the Poles, who received the sharp resistance these colonies offered. Wallerstein confuses a hierarchy of wage costs with a physical flow of products along a commodity chain (not common at the time, the international division of labour within stages of production being weak) with a political chain of command. He does not substantiate the claim that the semi-periphery absorbs political tension. It is however on this topic of the form of labour control that Wallerstein's political conclusions are most wild. The hierarchy of labour is sustained by two things, a recognition of the different 
status of labour at different places (racism) and the commodification of everything in the core including the costs of reproducing labour power borne elsewhere in the world by the sexist dismissal of such work as domestic and unproductive. Wage labour, then, is non-racist and non-sexist. In this sense it is socialist. I was frankly staggered to read Wallerstein's paeon to "free" labour: "Free labour is indeed a defining feature of capitalism, but not free labour throughout the productive enterprises. Free labour is the form of labour control used for skilled work in core countries whereas coerced labour is used for less skilled work in peripheral areas. The combination thereof is the essence of capitalism. When labour is everywhere free, we shall have socialism" ${ }^{[42]}$ I am reminded of Marx: "The sphere of circulation or commodity exchange, within whose boundaries the sale and purchase of labour-power goes on, is in fact a very Eden of the innate rights of man. It is the exclusive realm of Freedom, Equality, Property and Bentham.... When we leave this sphere of simple circulation or the exchange of commodities, which provides the 'free-trader vulgaris' with his views, his concepts and the standard by which he judges the society of capital and wage-labour, a certain change takes place, or so it appears, in the physiognomy of our dramatis personae. He who was previously the money-owner now strides out in front as a capitalist; the possessor of labour-power follows as his worker. The one smirks self-importantly and is intent on business; the other is timid and holds back, like someone who has brought his own hide to market and now has nothing else to expect but - a hiding." $[43]$

\section{Epistemology, mythology and politics}

\footnotetext{
.. Pellerin exclaimed:

"I don't want any of your hideous reality! What do you mean by reality, anyway? Some see black, some see blue, and the mob see wrong. There's nothing less natural than Michelangelo and nothing more powerful. The cult of external truth reveals the vulgarity of our times; and if things go on this way, art is going to become a sort of bad joke inferior to religion in poetry and inferior to politics in interest.

(Gustave Flaubert, Sentimental Education, 1869; Penguin edition, p. 58).
}

Humanity's stupid rationalism contains an unimaginably large element of materialism. This fear of error which everything recalls to me at every moment of the flight of my ideas, this mania for control, makes man prefer reason's imagination to the imagination of the senses. And yet it is always the imagination alone which is at work. Nothing, neither strict logic nor overwhelming impression, can convince me that I am not basing reality on a delirium of interpretation.

(Louis Aragon, Paris Peasant, 1926; Picador edition, p. 23).

The surrealism of Aragon makes impressionism an epistemology. At least Flaubert's Pellerin recognised something distinctive in art, projecting a "sort of Stock Exchange handling aesthetic interests" (p. 294) and asking of the revolutionary clubs of 1848 "I'd like to know where the candidate for Art is to be found" (p. 305). On each occasion the reverie, "the delirium of interpretation", is interrupted by a "large element of materialism": "What nonsense' grumbled a voice in the crowd. 'Always a lot of fancy ideas! Nothing significant'” (p. 294); “ 'We don't want any pictures!' retorted a thin man with red spots on his cheekbone" (p. 305). The mythology of the revolt of the democratic spirit clearly needed to be nurtured, as Pellerin had anticipated “... I think the Chambers ought to legislate in the interests of Art. A chair of aesthetics ought to be founded, with a professor who combined theory with 
practice, and who one day, I should hope, might succeed in educating the masses" (p. 144).

The world-systems project ought to be more than a matter of educating taste yet we are offered few guidelines for its systematic evaluation. There is a recklessness about the response of Taylor and Wallerstein to their critics which raises the suspicion that such guidelines may be loose or evanescent. When Taylor writes that "all assertions of truth are based on assumptions which ultimately involve a metaphysics of values", [44] the "ultimate" is almost immediate. Confession replaces analysis and a pluralistic balancing of commitments replaces morality. We choose our myths, Taylor tells us, so that "the clash between Wallerstein and his critics is one of 'opposing faiths'." ${ }^{[45]}$ It is hard to imagine that it is their misplaced faith in history-as-progress which leads Marxists to characterise pre-industrial Europe as a system of mercantile capitalism rather than, as Wallerstein would have it, a system of agricultural capitalism. Wallerstein may be empirically correct here but Faith does not seem to require empirical commitments of this type. In addition to this "if it feels good ..." epistemology, Taylor also recognises an alternative path to truth, a heuristic "suck it and see" approach. Of Wallerstein's categorisation of modes of production, based on Polanyi, Taylor tells us that "the test ... is in the fresh insights it provides". ${ }^{[46]}$ While slightly different from honesty and at least making some reference beyond the investigator's own imagination, "insight" is still a little vague, and would hardly stand up to the professedly "realist" critique with which Taylor bears down on positivist social science. ${ }^{[47]}$ In fact, Taylor wishes to place these insights at the service of the anti-systemic forces, working, apparently, for a kind of socialist United Nations, and to offer the world-systems project hostage to the success of this movement: "[the] whole scheme is ultimately tested through political practice". ${ }^{[48]}$ On this occasion the "ultimate" is unfortunately delayed until such time as Wallerstein's mythology is embraced by the anti-systemic forces. Their "ultimate" success will be the proof that the history informing the myth is useful. Corbridge has documented the way Radical Development Geography shields itself from empirical embarrassment by epistemological fiat: Marxism is science and we listen to no other. ${ }^{[49]}$ Taylor shares their conception of commitment as confession, he just has a different faith. Yet faith should come from "lessons", which is surely why Wallerstein embarked on his empirical studies in the first place. There is more at work in politics than "the imagination alone" and mythologies do not simply work or not: they embody more or less honest, decent and truthful historical accounts. It may disappoint literary critics, but when Aragon took political action seriously he embraced the very realism he had earlier rejected as an artist. Indeed Aragon took on the mythology of the Republican France attempting to wrest La Marseillaise from its jingoistic mission of irrigating French fields with bad foreign blood to align it with a communist party politics when they might prove what was the redder, the blood of the bourgeois or the blood of the worker ${ }^{[50]}$ Mythologies are contestable, historical social science is only one way of doing so and in this function it is to be judged as correct before useful. Mythologies may also be challenged artistically but let us recognise a division of labour here and not confuse the laws of development appropriate to these two spheres: 
À L'Internationale car voici

L'automne de tes jours, voici

L'Octobre où tombent tes derniers accents ...

(Louis Aragon, Réponse aux jacobins, 1934)

University of Liverpool,

P.O. Box 147,

Liverpool L69 $3 B X$

\section{Notes}

[1] P. J. Taylor, Political geography: world-economy, nation-state and locality (London 1985). I must thank Peter Taylor for an advance view of several of his recent essays and I hope he thinks the writer has used his grist fairly. I must also thank Stu Corbridge, Bill Gould, Peter Hugill and Sylvia Chant for advice, as well as seminar groups at Cambridge and A \& M Texas

[2] P. J. Taylor, The world-systems project, in R. J. Johnston and P. J. Taylor (Eds), A world in crisis? (Oxford 1986) 269-88, 286, 285; P. J. Taylor, The value of a geographical perspective, in R. J. Johnston, (Ed.) The future of geography (London 1985) 92-110, 97

[3] P. J. Taylor, Squire replying slowly, Studies in Comparative International Development 22 (1987) 72-81, 80. I. Wallerstein, Historical capitalism (London 1981). Since these remarks are offered in reply to Harvey's criticisms of Taylor, it is worth noting that it is precisely the lack of any explicit consideration of the state that Harvey notes as a weakness in his own work on global capitalism: D. Harvey, The limits to capital (Oxford, 1982); D. Harvey, The worldsystems trap, Studies in Comparative International Development 22 (1987) 42-7

[4] P. J. Taylor, The error of developmentalism, in D. J. Gregory and R. Walford (Eds), New horizons in human geography (London 1988)

[5] R. M. Jackson, Comment on 'The poverty of international comparisons: some methodological lessons from world systems analysis', Studies in Comparative International Development 22 (1987) 47-55; V. Prescott and R. Fincher, Comment on 'The poverty of international comparisons: some methodological lessons from world systems analysis', Studies in Comparative International Development 22 (1987) 55-69

[6] E. R. Wolf, Europe and the people without history (Berkley 1982)

[7] Wallerstein, Historical capitalism, 99

[8] I. Wallerstein, The modern world-system II. Mercantilism and the consolidation of the European world-economy $1600-1750$ (London 1980)

[9] Wallerstein, Historical capitalism, 59

[10] Wallerstein, The modern world-system II, 38-9

[11] Ibid., 57

[12] Ibid., 245

[13] Wallerstein, Historical capitalism, 40-1

[14] Taylor, Political geography, 28

[15] Ibid., 31

[16] Wallerstein, Historical capitalism, 7

[17] I. Wallerstein, The modern world-system. Capitalist agriculture and the origins of the European world-economy in the sixteenth century (London 1974) 3

[18] Cf. Ibid., 351

[19] Wallerstein, Historical capitalism, 23

[20] Ibid., 25

[21] Taylor, Political geography, 29

[22] The best defence that might be offered is that it is a generalisation from game theory but I can find no such argument in these works

[23] Wallerstein, Modern world-system I, 351

[24] Wallerstein, Historical capitalism, 7

[25] Wallerstein, Modern world-system I, 67

[26] R. A. Dodgshon, The European past. Social evolution and spatial order (London 1987)

[27] Wallerstein's riposte that the periphery was vital to development because to counter this is to imply a comparison with a counterfactual case which never existed (Europe minus trade with the periphery) is bizarre and suggests that everything that happens is as equally important as everything else; P. O'Brien, European economic development: the contribution of the 
periphery, Economic History Review 35 (1982) 1-18; I. Wallerstein, European economic development: a comment on O'Brien, Economic History Review 36 (1983) 580-5

[28] G. Therborn, Why are some peoples more unemployed than others? (London 1985)

[29] Dogshon, The European past, 243

[30] Wallerstein, Historical capitalism, 56-7

[31] Ibid., 57

[32] Ibid., 42

[33] Ibid., 63

[34] Ibid., 105-6

[35] Ibid., 106

[36] R. Brenner, The origins of capitalist development: a critique of neo-Smithian Marxism, New Left Review 104 (1977) 25-92

[37] Wallerstein, Modern world system I, 99-107

[38] Ibid., 51

[39] As Mintz observes, “... 'free' labour and 'slave' labour are not polar opposites, except abstractly; indeed there are many intermediate forms of semicoerced labour, depending on locale, time, and specific circumstances" S. W. Mintz, Sweetness and power. The place of sugar in modern history (Harmondsworth 1985) 236

[40] Wallerstein, Modern world system I, 350

[41] Ibid., 87

[42] Ibid., 127

[43] K. Marx, Capital. A critique of political economy Volume One, 1867. Penguin edition (London 1976) 280

[44] Taylor, The world systems project, 273

[45] Ibid., 280

[46] Ibid., 278

[47] P. J. Taylor, The poverty of international comparisons: some methodological lessons from world-systems analysis, Studies in Comparative International Development 22 (1987) 12-39

[48] P. J. Taylor, Chaotic conceptions, antinomies, dilemmas and dialectics: who's afraid of the capitalist world economy, Political Geography Quarterly 5 (1986) 87-93, 88

[49] S. Corbridge, Capitalist world development. A critique of radical development geography (London 1986)

[50] M. Vovelle, La Marseillaise. La guerre ou la paix, in P. Norra (Ed.), Les lieux de mémoire. I. La République (Paris 1984) 83-136, 129 (I praise/The Internationale over The Marseillaise.) Give way, $\mathrm{O}$ Marseillaise,/to The Internationale because this is/the autumn of your days, here is/the October upon which your last strains will fall ...) 